\title{
TOP3A Gene
}

National Cancer Institute

\section{Source}

National Cancer Institute. TOP3A Gene. NCI Thesaurus. Code C26594.

This gene plays a role in the regulation of DNA topology and recombination in somatic cells. 